\title{
End of the Affair
}





\section{End of the Affair}

THE COLLAPSE OF THE ANGLO-FRENCH

ALLIANCE, 1939-40

\section{Eleanor M. Gates}

UNIVERSITY OF CALIFORNIA PRESS

BERKELEY LOS ANGELES 
University of California Press

Berkeley and Los Angeles, California

(C) 1981 by Eleanor M. Gates

Printed in the United States of America

\section{9}

Library of Congress Cataloging in Publication Data

\section{Gates, Eleanor $\mathbf{M}$}

End of the affair. The collapse of the Anglo-French alliance, 1939-40

Bibliography: p.

Includes index.

1. World War, 1939-1945-Diplomatic history.

2. Great Britain-Foreign relations-France.

3. France-Foreign relations-Great Britain.

4. Great Britain-Foreign relations-1936-1945.

I. Title.

D750.G37 940.53'22 80-23585

ISBN 0-520-04292-1 
In memory of my father,

Payson Grier Gates

(1894-1955) 
